\title{
KEGIATAN LITERASI MEDIA SOSIAL DI SMP KATOLIK ABDI SISWA II JAKARTA BARAT
}

\author{
Roswita Oktavianti ${ }^{1}$ dan Sinta Paramita ${ }^{2}$ \\ ${ }^{1}$ Fakultas Ilmu Komunikasi, Universitas Tarumanagara Jakarta \\ Email:roswitao@fikom.untar.ac.id \\ ${ }^{2}$ Fakultas Ilmu Komunikasi, Universitas Tarumanagara Jakarta \\ Email: sintap@fikom.untar.ac.id
}

\begin{abstract}
ABSTRAK
Di era digital, makna literasi media semakin luas. Dari awalnya terkait persoalan melek huruf dan melek media, mulai bergeser pada bagaimana perilaku seseorang menggunakan media, serta apa saja konten yang diunggah dan dikonsumsi. Di Indonesia, pengguna aktif media sosial tergolong tinggi. Namun tingginya aktivitas di media sosial ini tidak sejalan dengan tingkat literasi media masyarakatnya. Kegiatan pengabdian kepada masyarakat Fakultas Ilmu Komunikasi Universitas Tarumanagara dilakukan dalam bentuk pembekalan literasi media sosial dengan sasaran siswa Sekolah Menengah Pertama (SMP). Kegiatan dilakukan di SMP Katolik Abdi Siswa II Jakarta Barat. Pembekalan dilakukan dengan memberikan pemahaman tentang penggunaan media sosial Instagram dan Youtube sebagai medium menyebarkan konten positif. Dari hasil observasi ditemukan bahwa setelah dilakukan pendampingan secara berkelompok, para siswa mampu membuat konten positif di Instagram. Dengan metode survei juga diketahui bahwa para siswa sebagian besar mampu menggunakan media sosial secara bijak mulai dari durasi penggunaan, konten yang diunggah, akun yang diikuti, hingga cara mencari pengikut. Namun, penggunaan media sosial ini masih perlu didampingi oleh orang dewasa dan aturan ketat di sekolah.
\end{abstract}

Kata kunci: Instagram; Literasi media sosial; Siswa SMP.

\section{PENDAHULUAN}

Menurut data yang dikeluarkan oleh The World's Most Literate Nations dari Central Connecticut State University (CCSU) pada 2016 menunjukan bahwa Indonesia menempati urutan 60 dari 61 negara berdasarkan tingkat kemampuan literasi (Miller \& McKenna, 2016). Selain itu, data Human Development Indicators (HDI) khususnya dalam literasi yang dikeluarkan oleh United Nations Development Programme, menunjukan hal serupa bahwa Indonesia menempati urutan 116 dari 186 negara (IHDR, 2019). Dari kedua data tersebut, nampaknya Indonesia masuk dalam darurat literasi.

Literasi adalah transformatif dan kreatif, bukan hanya melibatkan pemahaman terhadap sebuah teks, melainkan memperbaharui sebuah teks. Sementara itu, istilah media literacy, digunakan untuk tiga alasan. Pertama, kompetensi budaya yang terkait dengan identitas sosial. Bagian dari upaya seseorang untuk mengubah diri dari orang dengan jenis/tingkat tertentu, menjadi jenis/tingkat tertentu dalam dunia sosial. Kedua, koneksi antara literasi (media) cetak dan cara seseorang menggunakan media. Ketiga, suatu fenomena yang kompleks (Burn \& Durran, 2007). Indonesia menempati urutan kelima negara yang mengakses internet terbesar setelah China, India, Amerika Serikat, dan Brasil (Internet Top 20 Countries - Internet Users 2019, 2019). Survei yang dilakukan Asosiasi Penyelenggara Jasa Internet Indonesia (APJII) tahun 2016, menunjukkan pengguna internet di Indonesia mencapai 132,7 juta jiwa. Peningkatan terjadi di tahun 2017 sebanyak 143,26 juta jiwa dari total populasi penduduk Indonesia 262 juta orang. Peningkatan tesebut meningkat setiap tahun terlihat dari data terakhir yang dikeluarkan APJII di tahun 2018 dimana penetrasi pengguna internet tercatat mencapai 171,17 juta jiwa, atau meningkat $64.8 \%$ dari total penduduk Indonesia 254,17 juta orang (APJII, 2018). 
Lemahnya kemampuan literasi dan tingginya akses internet di Indonesia memiliki berbagai macam dampak, salah satunya informasi palsu (hoax) dan ujaran kebencian yang belakangan ini kerap dijumpai di media sosial. Kesalahpahaman dalam menyimpulkan atau memaknai informasi dapat berakibat buruk bagi pengguna internet tersebut. Seperti yang sering kita dengar tentang kasus hoax dan ujaran kebencian belakangan ini. Menurut laporan Daily Social: Distribusi Hoax di Media Sosial 2018, platform atau aplikasi media sosial yang digunakan untuk menyebarkan hoax di urutan pertama adalah Facebook sebanyak 77,76\%, selanjutnya WhatsApp 72,92\%, Instagram $60,24 \%$. Masih dari data yang sama terdapat $77,76 \%$ pengguna media sosial mengirimkan pesan ujaran kebencian tersebut kepada individu lain atau grup lain (Dailysocial, 2018)

Media sosial seolah membawa masyarakat ke wilayah luas dan hampir tanpa batas. Kondisi ini kemudian dimanfaatkan orang yang tidak bertanggungjawab menyebarkan hoax untuk menyerang pribadi dan kelompok (Juliswara, 2017). Perkembangan teknologi seharusnya diimbangi dengan peningkatan kemampuan literasi yang baik. Dengan selarasnya kemampuan literasi media dan teknologi, masyarakat Indonesia dapat mendapatkan manfaat untuk kesejahteraan.

Persoalan literasi media ini sudah banyak diulas oleh peneliti di bidang Ilmu Komunikasi. Hal ini menunjukan masalah literasi media di Indonesia masih menjadi tren yang belum terselesaikan hingga saat ini. Seperti penelitian terkait model penguatan literasi digital melalui pemanfaatan $e$ learning yang membahas tentang pemanfaatan e-learning untuk meningkatkan kemampuan literasi digital (Setyaningsih, Abdullah, Prihantoto, \& Hustinawaty, 2019). Kemudian penelitian selanjutnya terkait pengembangan konten positif sebagai bagian dari gerakan literasi digital yang membahas cara-cara pengembangan konten positif agar masyarakat dapat memahami pesan-pesan yang disampaikan (Rahmawan, 2018).

Dari sejumlah persoalan tersebut, maka kegiatan literasi di bidang Ilmu Komunikasi khususnya media sosial perlu dilakukan oleh tim kegiatan pengabdian kepada masyarakat. Dalam hal ini, literasi terkait dengan penggunaan media sosial. Tujuannya agar para siswa mampu menggunakan media sosial dengan tepat dan bijak sejak dini. Kegiatan literasi ini sebelumnya sudah dilakukan dua kali di tahun 2017 yaitu pada siswa SMA di Jakarta yaitu SMA Santo Kristoforus 1 Jakarta Barat dalam bentuk pembekalan tentang media sosial sebagai medium untuk menyampaikan nilai luhur budaya Indonesia (Oktavianti \& Loisa, 2017); dan di SMA Santa Theresia Jakarta Pusat dalam bentuk penyuluhan tentang menanggulangi pesan ujaran kebencian (Oktavianti \& Utami, 2019).

\section{METODE PELAKSANAAN}

\section{Pembekalan}

Kegiatan pengabdian kepada masyarakat dilakukan cengan cara Pembekalan kepada siswa-siswi SMP Katolik Abdi Siswa II yang terletak di Komplek Perumahan Taman Aries, Blok E9 No. 1. Kembangan, Jakarta Barat, DKI Jakarta 11620. Kegiatan dilaksanakan setelah siswa-siswi menyelesaikan ujian akhir semester yakni pada tanggal 14 Desember 2018 dari pukul 07.00 12.00 WIB. Jumlah siswa yang mengikuti pengenalan sebanyak 67 siswa-siswi.

Tim pelaksana baik dosen dan mahasiswa memberikan materi seputar media sosial (Instagram dan Youtube) melalui presentasi dan dukungan audio visual. Selanjutnya, tim pengabdi memberikan praktik menulis konten di media sosial. Kegiatan ini diselingi dengan permainan (games) berhadiah. 


\section{Survei}

Tim pelaksana menyebarkan kuisioner setelah pembekalan. Kuisioner tersebut berupa pertanyaan mengenai penggunaan media sosial Instagram. Terdapat dua jenis kuisioner yang dibagikan kepada para siswa yaitu kuisioner dengan responden yang memiliki akun Instagram, dan responden yang tidak memiliki akun Instagram. Kuisioner yang dibagikan tersebut ditujukan untuk mengukur sejauhmana penggunaan media sosial Instagram serta pemahaman para siswa dalam menciptakan konten positif di Instagram. Hasil kuisioner tersebut kemudian diolah sebagai bentuk laporan akhir kegiatan pengabdian kepada masyarakat.

\section{Observasi}

Setelah kegiatan tim pengabdi melakukan evaluasi berupa observasi terhadap konten yang diunggah para siswa di media sosial. Hal ini untuk mengetahui sejauhmana para siswa mempraktikkan ilmu yang telah diterima dalam pembekalan.

\section{HASIL DAN PEMBAHASAN}

Kegiatan pengabdian kepada masyarakat Literasi Media Sosial dilakukan pada Jumat, 14 Desember 2018 diikuti oleh 67 siswa-siswi dengan perincian kelas VII sebanyak 21 orang, kelas VIII sebanyak 23 orang, dan kelas IX sebanyak 23 orang. Jumlah siswa tersebut terdiri atas 38 putra dan 29 putri. Selain itu kegiatan ini juga didampingi oleh dua guru pendamping.

Kegiatan dimulai pada pukul 07.45 WIB di Ruang Musik Sekolah Abdi Siswa II, dan melibatkan enam mahasiswa Fakultas Ilmu Komunikasi Universitas Tarumanagara. Materi yang dibawakan sekitar konten positif di media sosial Instagram dan Youtube. Materi diberikan dalam dua sesi yakni sesi media sosial Instagram dan media social Youtube. Pada sesi media sosial Instagram, pembekalan dimulai dengan pemberian materi "Facts About Social Media". Materi ini menjelaskan tentang arti dari media sosial, macam-macam media sosial, dampak media sosial baik positif dan negatif, bagaimana menggunakan media sosial dengan baik, hingga hal-hal yang perlu dihindari.

Di sela-sela materi, tim mengajak para siswa untuk bermain dan menari bersama. Para siswa didampingi oleh tim dosen dan mahasiswa, membuat konten positif secara berkelompok, baik foto maupun keterangan foto (caption). Konten positif itu diunggah di media sosial Instagram untuk kemudian diberi nilai yang terbaik. Para peserta menggunakan hashtag/tagar \#sosmedyourid \#spreadlovenohate \#fikomuntar \#abdisiswa \#personalbranding.

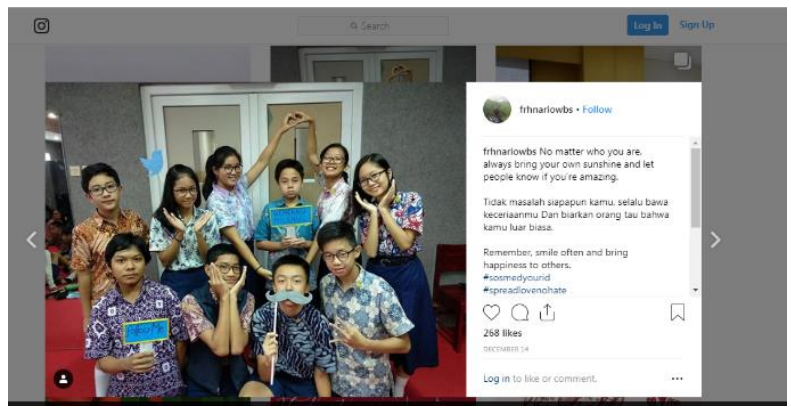

Gambar 1. Salah Satu Foto \& Caption yang Diunggah di Media Sosial

Pada sesi kedua, materi yang diberikan yakni seputar media sosial Youtube. Dari mulai fitur-fitur di dalam Youtube, cara membuat konten, hingga mengelola waktu dalam bermedia sosial (Youtube). Di sela-sela materi, tim juga menunjukkan video dampak negatif penggunaan media 
sosial berlebihan. Kegiatan ditutup dengan menari bersama, serta pemberian penghargaan atau apresiasi atas foto dan keterangan foto hasil kreativitas para siswa.

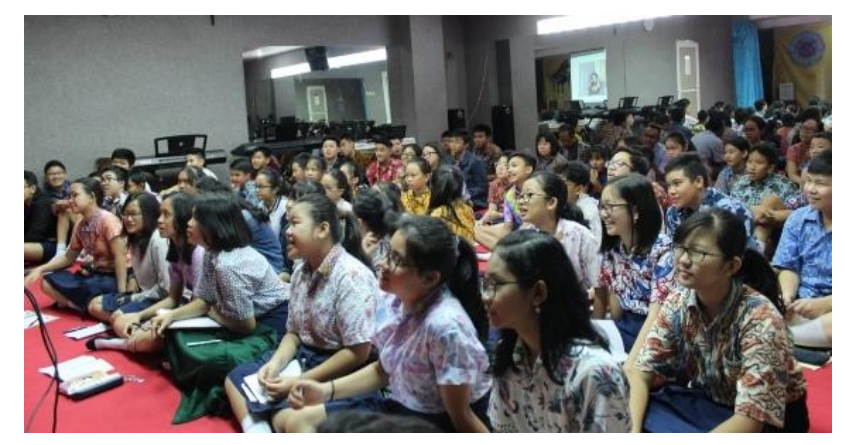

Gambar 2. Para Siswa SMP Katolik Abdi Siswa II Menyimak Materi Literasi Media Sosial

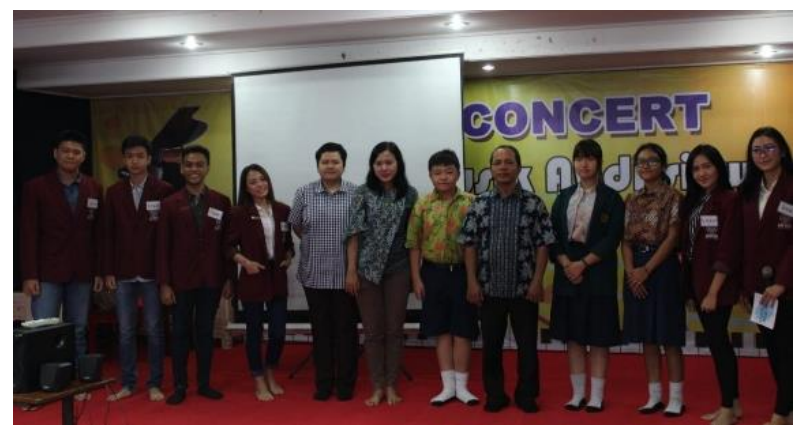

Gambar 3. Foto Bersama Tim Pengabdian Kepada Masyarakat, Roswita Oktavianti, S.Sos., M.Si., Sinta Paramita, SIP., MA., Kepala Sekolah, Drs. Antonius Mardiyono, M.M, Para Mahasiswa, dan ketua kelas SMP Katolik Abdi Siswa II.

Usai kegiatan pembekalan, tim membagikan kuisioner untuk mengetahui pemahaman para siswa setelah diberikan materi tentang literasi media sosial. Dari 67 siswa yang hadir, sebanyak 64 siswa mengisi kuisioner. Terdapat dua jenis kuisioner. Kuisioner pertama ditujukan bagi para siswa yang memiliki akun media sosial Instagram, sedangkan kuisioner kedua ditujukan kepada para siswa yang tidak memiliki akun Instagram.

Tabel 1. Memiliki Media Sosial Instagram

\begin{tabular}{ccc}
\hline & Frekuensi & Persentase \\
\hline Ya & 55 & 85,9 \\
Tidak & 9 & 14,1 \\
\hline Total & 64 & 100 \\
\hline
\end{tabular}

Tabel 1 menunjukkan bahwa dari 67 responden yang merupakan siswa-siswi SMP, sebanyak 85,9 persen memiliki akun media sosial Instagram, sedangkan sisanya 14,1 persen tidak memiliki akun media sosial Instagram. Ini menunjukkan bahwa Instagram merupakan media sosial yang popular di kalangan remaja pada jenjang SMP. 


\section{Siswa sebagai pengguna media sosial Instagram}

Tabel 2. Durasi Mengakses Media Sosial Instagram

\begin{tabular}{ccc}
\hline Durasi & Frekuensi & Persentase \\
\hline 1 jam & 12 & 21,8 \\
\hline 2 jam & 14 & 25,5 \\
\hline 3 jam & 10 & 18,2 \\
\hline 4 jam & 8 & 14,5 \\
\hline$>5$ jam & 11 & 20,0 \\
\hline Total & 55 & 100 \\
\hline
\end{tabular}

Tabel 2 menunjukkan bahwa sebanyak 25,5 persen siswa-siswi mengakses akun Instagram selama dua jam per hari, 21,8 persen mengakses selama 1 jam per hari, 20 persen mengakses selama lebih dari 5 jam perhari, 18,2 mengakses selama 3 jam perhari, dan 14,5 persen mengakses selama 4 jam perhari. Durasi akses terbanyak yakni 2 jam dan 1 jam per hari dikarenakan sebagian besar waktu dihabiskan di sekolah dimana penggunaan ponsel dilarang selama jam sekolah.

Tabel 3. Kurun Waktu Unggah Foto di Media Sosial Instagram

\begin{tabular}{ccc}
\hline Kurun waktu & Frekuensi & Persentase \\
\hline$>1$ bulan & 35 & 63,6 \\
\hline 1 bulan & 8 & 14,5 \\
\hline 1 minggu & 6 & 11.00 \\
\hline 1 hari & 4 & 7,3 \\
\hline$<1$ hari & 2 & 3,6 \\
\hline Total & 55 & 100
\end{tabular}

Tabel 3 menunjukkan bahwa sebanyak 63,6 persen siswa-siswi mengunggah satu foto dalam kurun waktu lebih dari satu bulan, 14,5 persen mengunggah satu foto dalam kurun waktu satu bulan, 11 persen mengunggah satu foto dalam kurun waktu satu minggu, 7,3 persen mengunggah satu foto perhari, dan 7,3 persen mengunggah lebih dari satu foto dalam satu hari. Ini menunjukkan bahwa para siswa yang berada pada usia 12-14 tahun ini terbilang selektif dalam mengunggah foto di media sosial Intagram mereka. Sebagian besar menggunggah foto dalam kurun waktu satu bulan bahkan lebih dari satu bulan.

Tabel 4. Membuka Akses Akun Media Sosial Instagram untuk Publik/Pengguna Lain

\begin{tabular}{ccc}
\hline & Frekuensi & Persentase \\
\hline Ya & 29 & 52,7 \\
\hline Tidak & 26 & 47,3 \\
\hline Total & 55 & 100 \\
\hline
\end{tabular}

Tabel 4 menunjukkan bahwa sebanyak 52,7 persen siswa-siswi membuka akun Instagram untuk publik, sementara 47,3 persen menutup akun Instagram untuk publik. Alasan para siswa membuka akun Instagram yakni: tidak tahu cara mengunci (private) akun, agar semakin banyak pengguna bisa melihat foto yang diunggah, menambah pengikut, kepentingan bisnis, memudahkan teman/kenalan mencari akun mereka, tidak ada informasi yang bersifat privasi/rahasia, hingga 
pemahaman tentang media sosial yang memang bersifat sosial/ untuk mengembangkan diri kepada publik.

Sementara, alasan para siswa menutup akun Instagram yakni lebih untuk menjaga privasi, selektif dalam memilih pertemanan/mengontrol follower, takut akun digunakan untuk penipuan/dimanfaatkan orang tidak dikenal, merasa lebih aman, keengganan foto dilihat oleh orang asing, banyaknya akun palsu (fake account), khawatir terjadi diskriminasi, serta berhati-hati dengan pengintai (stalker).

Tabel 5. Menggunakan Jasa Beli Pengikut (Follower)

\begin{tabular}{ccc}
\hline & Frekuensi & Persentase \\
\hline Ya & 2 & 3,6 \\
\hline Tidak & 53 & 96,4 \\
\hline Total & 55 & 100 \\
\hline
\end{tabular}

Tabel 5 menunjukkan bahwa hanya 3,6 persen atau 2 siswa dari 55 siswa yang mengaku membeli pengikut (follower). Sementara, sebanyak 96,4 persen siswa-siswi tidak menggunakan jasa beli pengikut (follower). Alasan siswa membeli pengikut yakni agar memiliki pengikut yang banyak. Sementara satu siswa menyatakan akun dikelola oleh pihak lain (manajemen) sehingga beli follower dilakukan oleh manajemen.

Alasan siswa tidak membeli pengikut yakni ilegal, sikap curang, tidak membawa manfaat, membuang uang, tidak mau membohongi diri sendiri, ingin follower yang murni, jujur dan positif dalam bermedia sosial, khawatir akun dibajak/di-hack, kuantitas follower bukan sesuatu yang penting, tidak tahu cara membeli follower, dan tidak percaya penjual follower.

Tabel 6. Akun yang Diikuti (Following)

\begin{tabular}{ccc}
\hline & Frekuensi & Persentase \\
\hline Keluarga \& kerabat & 42 & 76,3 \\
\hline Teman (sekolah, tempat ibadah, tetangga, dll) & 50 & 90,9 \\
\hline Artis/aktor idola (selebgram, youtuber, dll) & 48 & 87,2 \\
\hline $\begin{array}{c}\text { Tokoh yang dikagumi (presiden, pemuka } \\
\text { agama) }\end{array}$ & 25 & 45,4 \\
\hline Lainnya & 4 & 7,2 \\
\hline
\end{tabular}

Tabel 6 menunjukkan bahwa sebagian besar siswa atau 90,9 persen mengikuti akun teman-teman yaitu teman sekolah, teman di tempat ibadah, tetangga, dll. Kemudian mengikuti akun artis/aktor/idola sebanyak 87,2 persen, akun keluarga dan kerabat sebanyak 76,3 persen, tokoh yang dikagumi seperti presiden dan pemuka agama sebanyak 45,4 persen. Sisanya 7,2 persen siswa mengikuti akun lainnya. Lainnya yaitu akun fan base/basis penggemar, dan orang-orang yang kreatif. Ini menunjukkan bahwa para siswa SMP, sebagian besar mengikuti (menjadi follower) akun-akun yang mereka kenal dengan baik (keluarga dan kerabat, teman), serta akun idola/tokoh yang mereka kagumi.

Tabel 7. Foto/Gambar yang Diunggah

\begin{tabular}{ccc}
\hline & Frekuensi & Persentase \\
\hline Jalan-jalan/rekreasi & 33 & 60 \\
\hline
\end{tabular}




\begin{tabular}{ccc}
\hline Acara bersama keluarga, kerabat, teman & 34 & 61,8 \\
\hline Foto diri sendiri & 25 & 45,4 \\
\hline Lainnya & 8 & 14,5 \\
\hline
\end{tabular}

Tabel 7 menunjukkan bahwa sebanyak 61,8 persen siswa mengunggah foto pada acara bersama keluarga, kerabat, dan teman. Sebanyak 60 persen mengunggah foto jalan-jalan atau rekreasi, 45,4 persen menggunggah foto diri, dan sisanya 14,5 persen menggunggah foto lain-lain. Lain-lain disini yaitu idola, meme, game, dan karakter anime lainnya.

Ini menunjukkan bahwa konten yang diunggah oleh para siswa dekat dengan kegiatan /kehidupan mereka sehari-hari. Namun, survei ini belum memastikan jenis konten dari foto/gambar yang diunggah siswa seperti idola, meme, game, karakter anime. Hal ini perlu dilakukan observasi lebih lanjut.

\section{Siswa bukan pengguna media sosial Instagram}

Dari 64 responden, sebanyak 9 siswa tidak memiliki akun media sosial Instagram. Para siswa mengisi kuisioner kedua yang diperuntukkan bagi responden yang tidak memiliki media sosial Instagram.

Tabel 8. Alasan Tidak Memiliki Akun Instagram

\begin{tabular}{|c|c|c|}
\hline & Frekuensi & Persentase \\
\hline Tidak diperbolehkan orangtua & 1 & 11,1 \\
\hline Tidak punya waktu untuk mengelola & 3 & 33,3 \\
\hline Khawatir terjadi ketergantungan & 1 & 11,1 \\
\hline Lainnya & 4 & 44,5 \\
\hline Total & 9 & 100 \\
\hline
\end{tabular}

Tabel 8 menujukkan dari 9 responden yang tidak memiliki akun Instagram, sebanyak 4 siswa $(44,5 \%)$ tidak memiliki akun Instagram dengan alasan lain. Alasan lain ini yaitu tidak memiliki ponsel, belum membuat, dan tidak memiliki minat. Sebanyak 3 siswa $(33,3 \%)$ tidak memiliki akun Instagram dengan alasan tidak memiliki waktu untuk mengelola. Selain itu sebanyak masingmasing 1 siswa tidak memiliki akun Instagram dengan alasan tidak diperbolehkan orangtua dan khawatir mengalami ketergantungan.

Namun demikian terdapat 3 siswa memiliki akun media sosial lain yakni Facebook dan Youtube.

Tabel 9. Memiliki Rencana Membuat Akun Instagram dalam Waktu Dekat

\begin{tabular}{ccc}
\hline & Frekuensi & Persentase \\
\hline Ya & 3 & 33,3 \\
\hline Tidak & 6 & 66,7 \\
\hline Total & 9 & 100 \\
\hline
\end{tabular}

Tabel 9 menunjukkan bahwa dari 9 responden sebanyak 6 siswa (66,7\%) tidak berencana membuat akun Instagram dalam waktu dekat. Sementara 3 siswa $(33,3 \%)$ berencana membuat akun Instagram dalam waktu dekat.

Tabel 10. Tanpa Instagram, Merasa Tertinggal Informasi

\begin{tabular}{cc}
\hline Frekuensi & Persentase \\
\hline
\end{tabular}




\begin{tabular}{ccc}
\hline Ya & 0 & 0 \\
\hline Tidak & 9 & 100 \\
\hline Total & 9 & 100 \\
\hline
\end{tabular}

Tabel 10 menunjukkan bahwa dari 9 responden seluruh responden atau 9 siswa menyatakan, tanpa Instagram mereka tidak merasa tertinggal informasi.

\section{Perilaku menggunakan media sosial Instagram}

Dari kegiatan pengabdian kepada masyarakat ini dapat diketahui perilaku para siswa dalam menggunakan media sosial Instagram. Peneliti dari Universitas Gadjah Mada mengungkapkan bahwa kecakapan literasi digital, bukan hanya terkait keterampilan teknis dalam mengakses internet, melainkan kemampuan menyaring informasi dan hiburan, dan berbagai aplikasi di ponsel yang menarik bagi anak. Literasi bukan hanya sebatas proses seorang anak berinteraksi dengan internet, melainkan bagaimana interaksi tersebut berkontribusi terhadap aspek tumbuh kembang anak (Kurnia, Wendratama, Adiputra, \& Poerwaningtias, 2017). Di era digital saat ini, aktivitasme sosial dapat memanfaatkan berbagai lini komunikasi di internet seperti media sosial (Facebook, Instagram, Twitter, Youtube) dan situs pengumpul dukungan/petisi online (Syaripudin, Ahmad, Ningrum, Banyumurti, \& Magdalena, 2019).

Instagram merupakan media sosial yang popular di kalangan remaja pada jenjang SMP, dan SMA (Oktavianti \& Loisa, 2017; Oktavianti \& Utami, 2019). Namun para siswa SMP di Jakarta, khususnya, mengakses Instagram 1-2 jam per hari. Hal ini dikarenakan sebagian besar waktu dihabiskan di sekolah dimana penggunaan ponsel dilarang selama jam sekolah. Para siswa yang berusia 12-14 tahun ini juga terbilang selektif dalam mengunggah foto di media sosial Intagram mereka. Sebagian besar menggunggah foto dalam kurun waktu satu bulan bahkan lebih dari satu bulan.

Para siswa cenderung mengikuti akun yang mereka kenal atau mereka kagumi. Para sisw juga sebagian besar mencari pengikut (follower) secara alami. Sebagian dari siswa membuka akun mereka untuk publik, sementara sebagian lagi menutup akun mereka untuk publik. Siswa yang membuka akses akun mereka untuk pengguna lain lebih cenderung menganggap media sosial untuk bersosialisasi seperti mendapatkan teman atau pengikut. Konten yang diunggah juga dianggap tidak bersifat privasi. Sementara itu, para siswa yang menutup akun Instagram mereka tergolong selektif dalam memilih pertemanan/follower. Terdapat kekhawatiran akun mereka digunakan untuk hal-hal yang tidak bertanggungjawab, hingga kekhawatiran mengalami diskriminasi. Selain siswa SMP pengguna media sosial Instagram, terdapat siswa yang tidak memiliki akun Instagram. Walau jumlahnya sedikit, siswa yang tidak memiliki akun Instagram menganggap mereka tidak tertinggal informasi dengan teman-teman yang memiliki akun Instagram. Sebagian besar dari siswa yang tidak memiliki akun Instagram karena belum diizinkan menggunakan ponsel oleh orangtua atau tidak diperbolehkan orangtua, hingga tidak memiliki waktu untuk mengelola akun tersebut.

\section{KESIMPULAN}

Kegiatan pengabdian pada masyarakat ini menemukan bahwa para siswa merupakan pengguna aktif media sosial Instagram. Setelah dilakukan pembekalan, pendampingan secara berkelompok dan observasi, siswa sudah mampu mengunggah foto dan keterangan foto (caption) yang positif. analisis data dengan kuisioner juga menunjukkan, peserta yang berada di usia remaja (SMP), para siswa sebagian besar mampu menggunakan media sosial secara bijak. Hal yang dilakukan antara lain durasi penggunaan, konten yang diunggah, akun yang diikuti, hingga cara mencari pengikut. 
Namun penggunaan media sosial ini perlu didampingi oleh orang dewasa dan aturan tegas di sekolah.

\section{Ucapan Terima Kasih (Acknowledgement)}

Penulis menghaturkan terimakasih kepada Direktorat Penelitian dan Pengabdian Kepada Masyarakat Universitas Tarumanagara atas dukungan dana sehingga kegiatan ini bisa berjalan dengan lancar. Terimakasih juga disampaikan kepada para mahasiswa FIKOM Universitas Tarumanagara Angkatan 2018, Kepala Sekolah SMP Katolik Abdi Siswa II Bapak Drs. Antonius Mardiyono, M.M., para guru, dan siswa-siswi, sebagai mitra kegiatan pengabdian kepada masyarakat.

\section{REFERENSI}

APJII. (2018). Laporan Survei Penetrasi \& Profil Perilaku Pengguna Internet Indonesia 2018. Burn, A., \& Durran, J. (2007). Media Literacy in Schools: Practice, Production, and Progression. London: Paul Chapman Publishing.

Dailysocial. (2018). Laporan Daily Social: Distribusi Hoax di Media Sosial 2018. Retrieved July 13, 2019, from https://dailysocial.id/post/laporan-dailysocial-distribusi-hoax-di-m diasosial-2018

IHDR, I. H. (2019). Retrieved July 13, 2019, from http://hdr.undp.org/en/countries/profiles/IDN Internet Top 20 Countries - Internet Users 2019. Retrieved May 26, 2019, from https://www.internetworldstats.com/top20.htm

Juliswara, V. (2017). Mengembangkan Model Literasi Media yang Berkebhinnekaan dalam Menganalisis Informasi Berita Palsu (Hoax) di Media Sosial. Jurnal Pemikiran Sosiologi, 4(2), 142. doi:10.22146/jps.v4i2.28586

Kurnia, N., Wendratama, E., Adiputra, W. M., \& Poerwaningtias, I. (2017). Literasi Digital Keluarga, Teori dan Praktik Pendampingan Orangtua terhadap Anak dalam Berinternet. Yogyakarta: Center for Digital Society Fakultas Ilmu Sosial dan Ilmu Politik Universitas Gadjah Mada Yogyakarta.

Miller, J. W., \& McKenna, M. C. (2016). World Literacy How Countries Rank and Why It Matters, 1st Edition. Retrieved July 3, 2019, from http://www.ccsu.edu/wmln/rank.html

Oktavianti, R., \& Loisa, R. (2017). Penggunaan Media Sosial Sesuai Nilai Luhur Budaya di Kalangan Siswa SMA. Jurnal Pengabdian Kepada Masyarakat, 3(1), 86-95. doi:10.22146/jpkm.26925

Oktavianti, R., \& Utami, L. S. (2019). Penyuluhan Tentang Menanggulangi Ujaran Kebencian di SMA Santa Theresia Jakarta. Jurnal Panrita Abdi, 3(1), 32-40.

Rahmawan, D. (2018). Pelatihan Literasi Media Sosial Terkait Penanggulangan Hoaks Bagi Siswa SMA. Jurnal Pengabdian Kepada Masyarakat, 2(12), 1021-1024. Retrieved from http://jurnal.unpad.ac.id/pkm/article/view/20404

Setyaningsih, R., Abdullah, A., Prihantoto, E., \& Hustinawaty, H. (2019). Model Penguatan Literasi Digital Melalui Pemanfaatan E-Learning. Jurnal ASPIKOM, 3(6).1200-1215 doi:10.24329/aspikom.v3i6.333

Syaripudin, A., Ahmad, D., Ningrum, D. W., Banyumurti, I., \& Magdalena, M. (2019). Kerangka Literasi Digital Indonesia. Retrieved from http://literasidigital.id 